\title{
The Analysis of Worker Safe Behaviour based on the Antencendent Behaviour Consequence (ABC) Behaviour Model
}

\author{
Analisis Perilaku Aman Tenaga Kerja berdasarkan Model Perilaku Antencendent \\ Behaviour Consequence (ABC)
}

\author{
Anugrah Visar Rahman ${ }^{1}$, Endang Dwiyanti \\ PT. Biro Teknik Sinar Baru \\ ${ }^{1}$ Jl. Soekarno-Hatta No.795, Babakan Penghulu, Cinambo, Bandung City, West Java, 40293 Indonesia \\ ${ }^{2}$ Department of Occupational Safety and Health, Faculty of Public Health, Universitas Airlangga \\ Campus C Mulyorejo, Surabaya, East Java, 60115 Indonesia
}

\begin{abstract}
Introduction: PT. Kreasindo Wira Darma is an electrical construction company offering substation and electrical transmission installation in Indonesia. The common basic cause of work accident is unsafe behaviour and unsafe condition. This research aimed to analyze the safe behaviour of construction workers at Blimbing substation using behaviour-based safety approach and Antencendent, Behaviour, Consequence (ABC) theory. Method: This research was an observational descriptive study using cross-sectional design. The data were collected using questionnaire, observation, and interview. There were a total of 20 construction workers at PT. Kreasindo Wira Darma which became the respondents for this study, and total population was used as the samples. This study's variables include antencendent and consequence as independent variables and worker's safe behaviour as the dependent variable. Results: Most of construction workers had good knowledge by $90 \%$, good awareness by $90 \%$, all workers have good motivation and fulfilled need for safety by $100 \%, 18$ workers said that there were Occupational Health Safety (OHS) rules in effect at the company by $90 \%$, and workers said that they have received rewards/praises and punishments by $95 \%$. Results also showed that most cosntruction workers have applied safe behaviour at the workplace. Conclusion: Workers will consistently practice safe behaviour when they are equipped with knowledge, awareness, good motivation, compliance with Occupational Health Safety (OHS) rules, and are given reward and punishment.
\end{abstract}

Keywords: behavior-based safety, electrical construction, safe behaviour

\section{ABSTRAK}

Pendahuluan: PT. Kreasindo Wira Darma adalah perusahaan yang bergerak di bidang konstruksi listrik di Indonesia yang melayani jasa pemasangan gardu induk dan transmisi listrik. Hal yang biasanya menjadi penyebab dasar kecelakaan di tempat kerja adalah perilaku yang tidak aman serta kondisi yang tidak aman. Penelitian ini bertujuan untuk menganalisis perilaku aman pekerja konstruksi di gardu induk Blimbing menggunakan pendekatan behavior-based safety dan teori perilaku Antencendent, Behaviour, Consequence (ABC). Metode: Penelitian deskriptif observasional dengan desain penelitian cross-sectional. Metode: Pengambilan data yaitu dengan melakukan kuisioner, observasi, dan wawancara. Jumlah responden dalam penelitian ini adalah 20 pekerja konstruksi di PT. Kreasindo Wira Darma dan menggunakan total populasi sebagai sampel penelitian. Variabel dalam penelitian ini antencendet dan consequence sebagai variable bebas dan perilaku aman pekerja sebagai variable terikat. Hasil: Penelitian ini menunjukkan bahwa sebagian besar pekerja konstruksi memiliki pengetahuan yang baik; $90 \%$, kesadaran yang baik; $90 \%$, semua pekerja memiliki motivasi baik dan kebutuhan selamatnya terpenuhi; $100 \%, 18$ pekerja mengatakan bahwa dan dan berlaku peraturan K3 di perusahaan; $90 \%$, dan pekerja mengatakan bahwa mereka telah menerima reward atau pujian serta hukuman; 95\%. Hasil juga menunjukkan bahwa sebagian besar pekerja konstruksi telah berperilaku aman di tempat kerja. Simpulan: Tenaga kerja apabila memiliki

Corresponding Author:

Anugrah Visar Rahman

Email: visar.vio@gmail.com

Telephone: +6285231674453

\section{INTRODUCTION}

In implementing their duties, humans are always followed by possible danger arising from behaviour, working tools, or working environment. 
Therefore, workers need a condition when they feel safe while doing their work and which makes safety and health at work a necessity. Safety does not only entail material or money; it is one of the well-being indicators human must receive as well as a human right (Armbruster, 2013).

In the industrialization era, work productivity is highly needed in efforts to have quality products at work. Workplace bears risks of danger that can cause work accidents. According to Law Number 1 of 1970 concerning Work Safety, workplace is every room of field, closed or open, moving or static, that is often used by workers for business purposes and that has source of danger (Ministry of Manpower, 1970).

Number of work accident cases in Occupational Health and Safety (OHS) in Indonesia is still fairly high. International Labour Organization (ILO) recorded more than 2.34 million people died from work accident and diseases induced by work, which breaks down to approximately 114,148 cases of work accident and 1.09 million cases of disesase induced by work (Kristianti and Tualeka, 2019). According to Report by Ministry of Manpower and Transmigration, there were 130,923 cases of work accident in 2019 and 14,325 cases in 2020 (Pasaribu, 2020). The high figure in work accident has been a specific concern in every industry, pointing that safety and health of manpower is a top priority at work. Endeavors to protect manpower can be done with integration from various relevant parties such as company policy, programs, and the manpower itself so as to reduce the possibility of both financial and time loss (Ekasari, 2017).

Human has great share in the arising of accidents as research showed that $80-85 \%$ of accidents were caused by human negligence and error. An opinion even argued that all accidents are direct or indirectly caused by human error (Pasaribu, 2020). Such mistakes might come from factory owners, factory planners, flawed policy, contractors, machine makers, enterpreneurs, engineers, maintenance officers, and others (Budianto, 2014). The high number of work accident requires every company to boost work safety at their work sites. Companies in Indonesia have begun competing for zero accident recognition by committing to maintaining work safety, held firm by all workers and management.

Most companies in Indonesia today have applied an alternative for safety program, namely Behavior-Based Safety (BBS). It is a process that creates safety partnership between the management and workers with a sustainable focus on the attention and actions toward everyone, as well as the effort of safe behaviour. Implementing Behavior-Based Safety (BBS) can help identify unsafe behaviour and eliminate them, thus increasing safe behaviour for workers to prevent accidents (Pratiwi, 2018).

Preventing work accidents can be done by focusing on reducing unsafe behaviour. Identification of unsafe act or unsafe behaviour can be conducted in various ways; one of them is by using BehaviorBased Safety (BBS). The activation of BehaviorBased Safety (BBS) program at PT Denso Indonesia has managed to reduce the frequency of unsafe behaviour and increase the frequency of safe behaviour in radiation workers. Number of work accident at PT Denso Indonesia also saw a decline by $67-89 \%$ from the previous period after applying BBS program. Therefore, companies need to conduct analysis on the Behavior-Based Safety (BBS) implementation to assess its optimization (Ningsih and W. Ardyanto, 2013).

The Antencendent, Behaviour, Consequenece $(\mathrm{ABC})$ behaviour change model can be used to design interventions needed to boost certain behaviour at individual, group, and organization level. Antencendent, Behaviour, Consequenece (ABC) is an effective method to learn why behaviour happens since this model believes that behaviour happens for a reason or a trigger. In this case, triggers can be antencendents and consequences that follow an act or behaviour. Using the Antencendent, Behaviour, Consequenece (ABC) model will allow safe behaviour to be practiced by workers (Geller, 2005).

A research conducted by Kristianti \& Tualeka, (2019) explained that several attempts to increase safe behaviour were made at PT. Pupuk Kalimantan Timur. It included antencendents that affects behaviour such as the role of management, workers' compliance with Occupational Health Safety (OHS) rules, positive perceptions on the danger and risks of work accident, good level of knowledge, good motivation and awareness, and fulfilled need for safety.

The study's results also explained that there were consequences of positive reinforcement and punishment, but they were not the factors with significant impact (Radityo, 2019). Another study by Chairunnisa and Suwandi (2018) mentioned that Occupational Health Safety (OHS) facilities such as Personal Protective Equipment (PPE) and rules 
supporting work safety were available at PT. X. The results showed that most of its workers have good attitude and efficacy due to the implementation of Behavior-Based Safety (BBS) in the company (Sirait and Paskarini, 2017).

PT. Kreasindo Wira Darma's headquarter is located in Tenggilis Mejoyo street, Kali Rungkut, Surabaya city, East Java. The company owns several projects in various sites such as Surabaya, Jakarta, and Malang. Its role in Blimbing substation project includes excavation, reinforcing, ceiling and wall construction, casting, electrical installation, and care. This research took place in A. Yani Street No. 59, Purwodadi, Blimbing Subdistrict, Malang city, East Java.

The project sites only provide four gallons of drinking water for the workers. They were working on a target set by the company, despite being quite high in number. Such activity poses danger risks that threaten workers, which include slipping, being struck down, falling from height, dehydration, excessive weight carrying, getting electrocuted, burning, even exploding and possible biological danger. Such dangers entail risks of wound, injury, or even loss of life.

To increase safety and health of workers, the company took various measures formulated in the Occupational Health Safety (OHS) policy and commitment. One of them was Behavior-Based Safety (BBS), which aimed to reduce number of accidents caused by construction activities. Based on field observation, unsafe behaviour that induced accident were still found in the project sites, such as lack of workers' concern to use Personal Protective Equipment (PPE), failure to follow the procedure, and neglected Occupational Health Safety (OHS) norms. Such unsafe behaviour can be pushed to minimum by implementing Behavior-Based Safety (BBS) to learn workers' safe behaviour with antencendent, behavior, dan consequence analysis factors based on $\mathrm{ABC}$ theory model.

This study aimed to analyse safe behaviour of PT. Kreasindo Wira Darma's construction workers in Blimbing Substation using ABC behaviour change model with antencendent factors of knowledge, awareness, need for safety, motivation, and company rules on OHS. The behaviour is safe behaviour, while the consequence includes positive reinforcement and punishment. Results of this study can serve as suggestion and consideration to improve workers' behaviour and increase the implementation of Behavior-Based Safety (BBS) at PT Kreasindo Wira Darma in Blimbing Substation project.

\section{METHOD}

This study was a descriptive observational researrch since it was conducted by directly observing the situation and variables in the site. Cross-sectional design was used as the researchers conducted the study by observation during certain period of time, namely at the time of the field research.

The study took place in Blimbing electrical substation as one of PT. Kreasindo Wira Darma's projects. It began with proposal making, and data collection was carried out from January to March 2020. This research has also gained ethical clearance from Faculty of Public Health of Universitas Airlangga (FKM UNAIR) No.32/EA/KEPK/2020.

The population of this study was all construction workers, which included 20 workers at PT. Kreasindo Wira Darma. The samples were the total population, namely all construction workers at PT. Kreasindo Wira Darma

Independent variables included factors serving as antencendent, namely knowledge on danger factors and safe behaviour, awareness to behave safely, motivation to behave safely, need for safety, company rules on Occupational Health Safety (OHS), and factors serving as consequence (positive reinforcement and punishment). Meanwhile, the dependent variables included behaviour, which was safe behaviour of construction workers.

Data were collected from primary data, which included data from interview and observation using Critical Behavior Checklist (CBC), while the secondary data were from the company.

Total safe behaviour was measured by using the following Safe Behavior Index (Geller, 2005).

Safe Behaviour Index $=\frac{\text { Safe Observed }}{\text { Safe Observed }+ \text { Unsafe Observed }}+100 \%$

The percentage of Safe Behavior Index was obtained from the above calculation, which was then classified into 3 categories: good, fair, and poor. "Good" category was given to Safe Behaviour Index percentage $\geq 85 \%$; "fair" was given to Safe Behaviour Index percentage at between $60 \%$ and $84.9 \%$; and "poor" was given to Safe Behaviour Index percentage $\leq 59.9 \%$. The categories in determining Safe Behaviour Index were not clearly 
explained (Geller, 2005), but there were calculation examples showing that the Safe Behavior Index calculation result at $85 \%$ belongs to good category, and therefore the number was used as reference. The categories have also been used in the previous studies (Ekasari, 2017).

The collected data were then processed manually by checking the identity of each construction worker who became the respondent. Complete check was carried out on the data filling instruments, which included editing, coding, counting, entering, sorting, and tabulating.

Data were collected through questionnaire, critical behavior checklist observation sheet, while the secondary data were from the company, and interview result was then presented as text and tables. Next, analysis was carried out, presented with explanation from descriptive research data and summed up with the previously identified variables. Results of analysis were then connected to the Antencendent, Behaviour, Consequence (ABC) behaviour model theory to make conclusions of the study.

\section{RESULTS}

\section{Factors that Serve as the Antencenden}

Level of knowledge on Occupational Health Safety (OHS) and safe behaviour includes several matters related to how to create safe condition, e.g. by practicing safe behaviour and safe condition in the surrounding. Awareness can be categorized into two: good and poor.

Need for safety is among the basic needs of human, which includes a sense of being protected and feeling safe and comfortable while at work. Need for safety includes provision of safety guarantee, safe and comfortable workplace with supporting environment, availability of Personal Protective Equipment (PPE), enough working and resting hours to work conveniently, and some other factors. Based on the distribution in need for safety aspect, all respondents $(100 \%)$ claimed that they had all their needs met. Distribution results in this aspect show that all respondents $(100 \%)$ had good motivation to practice safe behaviour at work.

Looking to the results of observation and interview to PT. Kreasindo Wira Darma's management, the researchers learned that there was a management role that was going well, and the Occupational Health Safety (OHS) management system, competent human resource and equipment
Table 1. Distribution of Knowlodge of Construction Workers at Blimbing Substation in 2020

\begin{tabular}{|c|c|c|}
\hline$\underset{\substack{\text { Knowledge } \\
\text { L e v e l }}}{O \text { f }}$ & Frequency (n) & Percentage $(\%)$ \\
\hline Good & 18 & 90 \\
\hline Poor & 2 & 10 \\
\hline Total & 20 & 100 \\
\hline
\end{tabular}

Table 2. Distribution of Awareness of Construction Workers at Blimbing Substation in 2020

\begin{tabular}{ccc}
\hline Awareness & Frequency (n) & Percentage (\%) \\
\hline Good & 18 & 90 \\
Poor & 2 & 10 \\
\hline Total & 20 & 100 \\
\hline
\end{tabular}

Table 3. Distribution of Positive Reinforcement of Construction Workers at Blimbing Substation in 2020

\begin{tabular}{ccc}
\hline $\begin{array}{c}\text { Positive } \\
\text { Reinforcement }\end{array}$ & Frequency (n) & Percentage (\%) \\
\hline Ever & 19 & 95 \\
Never & 1 & 5 \\
\hline Total & 20 & 100 \\
\hline
\end{tabular}

were available, which is part of the management work program. The company had several Occupational Health Safety (OHS) programs, which covers daily toolbox meeting to discuss performance evaluation and achievement targets. Results of interview with Safety and Health Environment and secondary data showed that there were several programs and activities at PT. Kreasindo Wira Darma that were considered substantial to the company, namely: Occupational Health Safety (OHS) training schedule, daily report; Occupational Health Safety (OHS) meeting with company leaders, accident reports, risk identification, workers' health status report, and PPE availability report. Some of them, included in the company's Occupational Health Safety (OHS) regulation, are work procedure, norms on how to work properly, and information on the danger of work accident. The company regulations are applied as a guidance and reference in working.

Company regulations are applicable as guidance and reference in working according to the proper methods. They contain firm principles of application and violators will be given sanction. Distribution in this aspect showed that all respondents (100\%) claimed that there were applicable Occupational Health Safety (OHS) regulations in the company. 
Table 4. Distribution of Punisment of Construction Workers at Blimbing Substation in 2020

\begin{tabular}{ccc}
\hline Punisment & Frequency (n) & Percentage (\%) \\
\hline Ever & 19 & 95 \\
Never & 1 & 5 \\
\hline Total & 20 & 100 \\
\hline
\end{tabular}

Table 5. Distribution of Safe Behaviour of Construction Workers at Blimbing Substation in 2020

\begin{tabular}{ccc}
\hline Safe Behaviour & Frequency (n) & Percentage (\%) \\
\hline Good & 9 & 45 \\
Fair & 11 & 55 \\
\hline Total & 20 & 100 \\
\hline
\end{tabular}

\section{Factors that Serve as the Consequence}

Positive reinforcement will be able to shape better behaviour than the initial, which is actually wanted or needed by an individual. It can be in the form of praise, awards, and promotion as a form of appreciation form the company.

Punishment is given when someone does not follow the work procedures. It comes in various forms, including sanction for not wearing Personal Protective Equipment (PPE), sanction for not practicing safe behaviour while working.

\section{Safe Behavior of Electrical Construction Workers}

Safe behaviour can be affected by some factors. Safe behaviours among construction workers can be seen through direct observation on their activities during work, how they do work properly, supporting workplace condition, and some other aspects distribution of safe behaviour can be seen in the following table 5 .

Based on Table 5, we can learn that most respondents $(55 \%)$ have practiced safe behaviour in a fair level while working at PT. Kreasindo Wira Darma.

Cross Distribution of worker's safe behaviour and several factors that served as antencendent can be seen in Table 6 . Table 6 indicates that most repondents with good knowledge $(50 \%)$ have practiced safe behaviour in a fair level. Most workers with good awareness $(50 \%)$ have practiced safe behaviour in fair level, while most workers with poor awareness $(100 \%)$ also have practiced safe
Table 6. Cross Distribution of Safe Behaviour of Construction Workers with Factors Serving as Antencendent at PT. Kreasindo Wira Darma in 2020

\begin{tabular}{ccccccc}
\hline & \multicolumn{3}{c}{ Safe Behaviour } & \multirow{2}{*}{ Total } \\
\cline { 2 - 5 } Antencendent & \multicolumn{2}{c}{ Good } & \multicolumn{2}{c}{ Fair } & & \\
\cline { 2 - 5 } & $\mathbf{n}$ & $\%$ & $\mathbf{n}$ & $\%$ & N & $\%$ \\
\hline Knowledge & & & & & & \\
Good & 9 & 50 & 9 & 50 & 18 & 100 \\
Poor & 0 & 0 & $\underline{2}$ & 100 & 2 & 100 \\
\hline Awareness & & & & & & \\
Good & 9 & 50 & 9 & 50 & 19 & 100 \\
$\quad$ Poor & 0 & 0 & $\underline{2}$ & 100 & 1 & 100 \\
\hline Motivation & & & & & & \\
Good & 9 & 45 & 11 & 55 & 20 & 100 \\
\hline Need for Safety & & & & & & \\
Fulfilled & 9 & 45 & 11 & 55 & 20 & 100 \\
\hline OHS Rules & & & & & & \\
Fulfilled & 9 & 50 & 9 & 50 & 18 & 100 \\
Not Fulfilled & 0 & 0 & $\underline{2}$ & 100 & 2 & 100 \\
\hline
\end{tabular}

Table 7. Cross Distribution of Safe Behaviour of Construction Workers with Factors Serving as Consequence at Blimbing Substation in 2020

\begin{tabular}{cccccccc}
\hline & \multicolumn{4}{c}{ Safe Behaviour } & \multirow{2}{*}{ Total } \\
\cline { 2 - 6 } Consequence & \multicolumn{2}{c}{ Good } & \multicolumn{2}{c}{ Fair } & & \\
\cline { 2 - 6 } & $\mathbf{n}$ & $\%$ & $\mathbf{n}$ & $\%$ & N & $\%$ \\
\hline Positive & & & & & & \\
Reinforcement & & & & & & \\
Ever & 9 & 47.4 & 10 & 52.6 & 19 & 100 \\
Never & 0 & 0 & $\underline{1}$ & 100 & 1 & 100 \\
\hline Punishment & & & & & & \\
Ever & 9 & 47.4 & 10 & 52.6 & 19 & 100 \\
Never & 0 & 0 & $\underline{1}$ & 100 & 1 & 100 \\
\hline
\end{tabular}

behaviour in fair level. Most workers who claim that they need for safety while working is met $(55 \%)$ also have practiced safe behaviour in a fair level, while the rest $(45 \%)$ claimed that their need for safety was met and have behaved safely in a good level. Most construction workers claiming to hold good motivation while working (55\%) also have behaved safely, and the remaining (45\%) who claimed to have good motivation while working has practiced safe behaviour in a good level. Most workers stating that there were Occupational Health Safety (OHS) rules in the company $(50 \%)$ have behaved safely in a fair level. 
Cross distribution of safe behaviour and factors serving as consequence can be seen in Table 7. Table 7 shows that most construction workers who have ever received positive reinforcement (47.4\%) such as praise and promotion have practiced safe behaviour in a good level, while most workers who claimed to never receive positive reinforcement $(100 \%)$ have practiced safe behaviour in a fair level. Most workers who claimed to have received punishment from the company $(47.4 \%)$ have practiced safe behaviour in a good level, while most workers who claimed to never receive punishment during their tenure in the company $(100 \%)$ have practiced safe behaviour in a fair level.

\section{DISCUSSION}

\section{Factors that Serve as the Antencendent}

Antencendent is always the basis of one's behaviour before the behaviour happens. Candra (2015) argued that antencendent can cause a behaviour to happen, but also not to happen. Factors that serve as antencendent at PT Kreasindo Wira Darma's construction division include knowledge on danger factor and safe behaviour, awareness, motivation to do safe behaviour, need for safety, and the company's Occupational Health Safety (OHS) rules. Such factors will affect the respondents' behaviour in this research when they work. Antencendent here works as triggers that give a reason for someone to do something.

\section{Knowledge}

Knowledge is the result of knowing from someone about a particular object that they get from their senses. Something that can be seen, heard, felt, and conveyed will become an understanding or new knowledge (Candra, 2015). Kamus Besar Bahasa Indonesia (KBBI) stated that knowledge is everything about what is known or intelligence (KBBI, 2016). It can affect one's way of thinking and behaving. Generally, good knowledge will result in good thinking and behaviour. However, not all good knowledge result in good behaviour since every behaviour is based on many factors other than knowledge. Low level of knowledge basically can cause someone to not know about something, but when other factors support the safe behaviour, it can still happen (Syahfudin, 2019).

Workers' knowledge must be constantly improved through training on the potential danger and risks caused by their work. Training materials can be given during the toolbox meeting before working every day, allowing workers to learn the risks of their work and create safe environment at work. However, knowledge improvement does not always cause change in behaviour (Budianto, 2014).

\section{Awareness}

Safe behaviour based on awareness creates the meaning that people actually feel and consciously become the grounds for someone to do something. If someone is aware of something, they directly will feel the result of their own thinking and opinion. Someone who is aware to do something will know that they themselves want and will do it (Brito, 2017).

The research results showed that at PT. Kreasindo Wira Darma, most of the construction workers who became respondents had good awareness to practice safe behaviour at work, while some other had poor awareness. It can be caused by the willingness and ability to do safe behaviour. When a worker has good awareness, safe behaviour will follow since the awareness is already in them. Someone will unconsciously practice safe behaviour due to other underlying factors that make them do it (Chairunnisa and Suwandi, 2018).

The research results showed that at PT. Kreasindo Wira Darma, most construction workers had good awareness of safe behaviour at work. It indicates that they were aware, willing, and able to practice safe behaviour. Additionally, a sense of care among the workers also supports the safe behaviour as they will greet and remind each other whenever unsafe behaviour occurs at work. Workers can be considered to have awareness if they do not feel forced to do safe behaviour regardless of the sanction applied by the company (Radityo, 2019). When respondents only use Personal Protective Equipment (PPE) during inspection or during toolbox meeting from Occupational Health Safety (OHS) staff or management and think that Personal Protective Equipment (PPE) should be worn merely as an obligation at work, then in this case the respondents can be considered to have poor awareness.

\section{Need for Safety}

Maslow's hierarchy of needs theory explained that human needs are constituted of a hierarchy of needs consisting of five levels, which will be achieved according to the level of importance of the 
basic human needs. The needs include physiological needs, security needs and work safety (the sense protection from physical and emotional harm at workplace while working), social needs, and selfactualization needs (Maslow, 1970).

The need for safety is related to self-protection for construction workers from workplace dangers that should be provided by companies in order to manifest safe behaviour among workers (Syahfudin, 2019). To achieve that, companies must provide, among others, safety equipment, PPE availability, sufficient working hours, and safe workplace. Safe behaviour can occur when the need for security and safety at work is provided and fulfilled (Pasaribu, 2020). Research results showed that construction workers have received guarantee for safety need from the company. Receiving such guarentee will make them feel safe and comfortable at work, which leads to work productivity. Another factor is a sense of confidence in personal safety obtained from the fulfilled need for safety (Putri, Martiana and Rahman, 2020).

Brito (2017) stated that factors of experience, same post-assignment, and familiar environment could affect people to behave unsafely and keep doing it as it is fun, convenient, and time saving; and this behaviour tends to repeat. Chain of motivation consists of needs, wants, tension, behaviour, and satisfaction that generate behaviour (Anisah and Mulyono, 2020). Need for safety is related to protection of workers from harm at work that should be met by the company to have safe behaviour among workers.

\section{Motivation}

Motivation is a reason for someone to act in order to achieve their life's needs (Septiani, 2018). Good motivation can be shown by supporting factors that encourage workers to practice safe behaviour and work according to the rules or procedures. Rewards given to workers for their safe behaviour can be a motivation to them, encouraging them to work in safe behaviour and motivating other workers to participate. Direct care and support among workers, supervisors, and company leaders can motivate workers to work with safe behaviours (Maulana, 2012). Also, motivation can be given to remind those who violate the rules to not repeat their mistakes. Workers believe that punishment can motivate them to behave safely, and rewards are seen as more encouraging than just punishment/ sanction. The management thinks that rewards are effective consequence for practicing safe behaviour (Irlianti, 2014).

\section{Safety Rules}

Management of PT. Kreasindo Wira Darma has carried out their role well. This is on the grounds of, among others, proper Occupational Health Safety (OHS) management system, human resources, and equipment that suit the workers' needs. The company has several Occupational Health Safety (OHS) programs; one of them is daily toolbox meeting before work to talk about performance evaluation and achievement target.

According to Maulana (2012), rules are written document containing documentation on standards, norms, and policy of the company that aims to create the desired behaviour. Safety regulation will be deemed effective when it is made in a written form, then communicated and discussed with all workers involved in the workplace.

The applicable regulation at PT. Kreasindo Wira Darma includes Standard Operating Procedure (SOP), work instructions, work standards, equipment use, Occupational Health Safety (OHS) norms, posters and slogans on Occupational Health Safety (OHS). Rules and policy that apply in the company have been working fairly well, proven by the decision made to workers violating the rules such as direct reprimand, warning, written letter, even termination of employment.

Results from direct observation showed some misalignments between Occupational Health Safety (OHS) policy and workers' safe behaviour. Despite having learned all Occupational Health Safety (OHS) rules in the company, construction workers still deliberately violate the rules, e.g. saying that they did not know the Standard Operating Procedure (SOP). Such thing occurred due to the lack of tight supervision from the safety officers as they only do it at certain times.

Work supervision is mostly carried out by the project foreman, yet they do not properly understand the function and role of Occupational Health Safety (OHS). Such result showed the lack of commitment among workers to behave safely as well as the lack of commitment on Occupational Health Safety (OHS) from the management's side. (Chairunnisa and Suwandi, 2018) believes that among the strategies for behaviour change is power and authority such as binding rules and legislation to be obeyed by all people. 


\section{Factors that Serve as the Consequence}

The positive reinforcement given to the construction workers can support and encourage them to practice safe behaviour. One of the examples is through supervisor and company leader who give praise and reward, even promotion, to those who behave safely. Such measure will inject spirit and encourage them to work according to Standard Operating Procedure (SOP). New behaviour or change to better and safer behaviour by the workers can be based on factors that serve as consequence in the form of positive reinforcement and punishment they received before. Punishment given to violators and those who behave unsafely can be something frightening or avoided, e.g. getting reprimanded by the the company leader, administrative sanction, and incentive cut due to the violation.

List of behaviours observed in this study, available in the Critical Behavior Checklist (CBC), includes Standard Operating Procedure (SOP), Housekeeping (5S), Body Positioning (Ergonomics and Manual handling), Personal Protective Equipment (PPE), Communicating, Workshop, Tools Equipment, Body Protecting and Pacing of Work, and Driving of work. Unsafe behaviour found among the respondents are not using Personal Protective Equipment (PPE) properly, i.e. inconsistency in helmet and safety shoes use as they claim to feel discomfort to use it all the time, and lack of tight supervision by the safety officers as they only do it at certain times, leaving the workers feeling unsupervised. Another finding is workers joking while working, which will put them and others in danger when their concentration is split and turn themselves away from the Standard Operating Procedure (SOP) corridor.

This research thus showed that the results are in line with the Antencendent, Behaviour, Consequenece $(\mathrm{ABC})$ theory that mentions factors serving as antencendent and consequence. Factors that serve as antencendent can trigger or stimulate behaviour and will generate factors that serve as consequence to be treated as new behaviour in this research. There are 2 types of consequence affecting one's behaviour, namely positive reinforcement and negative reinforcement (punishment). The frequency of each behaviour may increase or decrease based on the consequences. When someone practices safe behaviour, they will get good consequence or give benefit; and when someone practices unsafe behaviour they are subject to sanction or punishment as the consequence of what they do (Anisah and Mulyono, 2020).
Positive reinforcement can be implemented by company leader giving praise, appreciation, even promotion to workers who practice safe behaviour. They can also encourage other workers to be willing and able to work in line with the Standard Operating Procedure (SOP). New behaviour or behaviour change to be better and safer among workers can also depart from or is triggered by consequences of positive reinforcement and punishment they obtained from previous experience (Putri, Martiana and Rahman, 2020).

\section{CONCLUSION}

Building upon the study results, it can be concluded that results show that safe behaviour among construction workers lands on "fair" cetagory as the highest score, which includes proper selection and use of Personal Protective Equipment (PPE) based on the worker's type and comprehension of Standard Operating Procedure (SOP) by all workers. Thus, it can be concluded that workers will consistently practice safe behaviour when they are equipped with knewledge, awareness, good motivation, compliance with Occupational Health Safety (OHS) rules, and are given reward and punishment.

\section{ACKNOWLEDGEMENT}

I would like tou convey my gratitude to all parties who have helped me in this study, especially the respondents. This paper would not have happened without God Almighty and support form PT. Kreasindo Wira Darma. I also thank Faculty of Public Health Universitas Airlangga for the insights and experience I was exposed to. Special thank is given to Mrs. Endang Dwiyanti, Dra., M.Kes. for her wholehearted support and guidance during the article writing, as it is her kindness that built my spirit and motivation. My gratitude is also for those with nonstop prayers and encouragement: my parents, big sister, and all members of family. This is also for my close friends as their help has brought me to this point. May God return every good you did.

\section{REFERENCES}

Anisah, S. and Mulyono, M. (2020) 'Correlation between Individual Characteristics and Workload toward Occupational Stress of Social Undesirables Facilitators', The Indonesian Journal of Occupational Safety and Health, 9(1), pp. 12-20. 
Armbruster, D. (2013) Keselamatan dan Kesehatan Kerja Sarana Untuk Produktivitas, Clinics in Laboratory Medicine. 33(1), 50-60.

Brito, G. T. (2017) 'Analisis Aspek Pembentuk Budaya K3 dengan Kepatuhan Penggunaan APD pada Pekerja Produksi Resin Di Sidoarjo', The Indonesian Journal of Occupational Safety and Health, 4(2), pp. 134-143.

Budianto, F. (2014) 'Pengaruh Keselamatan Dan Kesehatan Kerja terhadap Komitmen Organisasional Karyawan pada Bagian Produksi PT Sumber Kencana di Bojonegoro', Agora, 2(1), pp. 589-594.

Candra, A. (2015) 'Hubungan Faktor Pembentuk Perilaku dengan Kepatuhan Penggunaan Alat Pelindung Telinga pada Tenaga Kerja di PLTD Ampenan', The Indonesian Journal of Occupational Safety and Health, 4(1), pp. 8392.

Chairunnisa, C. R. and Suwandi, T. (2018) 'Evaluasi Pelaksanaan Inspeksi APD di $\mathrm{H}_{2}, \mathrm{CO}_{2}$ Dan Dry Ice Plant Di PT. X Kawasan Gresik', The Indonesian Journal of Occupational Safety and Health, 6(2), pp. 197-206.

Ekasari, L. E. (2017) 'Analisis Faktor yang Memengaruhi Kecelakaan Kerja pada Pengoperasian Container Crane di PT X Surabaya Tahun 2013-2015', The Indonesian Journal of Occupational Safety and Health, 6(1), pp. 124133.

Geller, E. S. (2005) 'Behavior-Based Safety and Occupational Risk Management', Behavior Modification, 29 (3), pp. 539-561.

Irlianti, A. (2014) 'Analisis Perilaku Aman Tenaga Kerja Menggunakan Model Perilaku ABC', The Indonesian Journal of Occupational Safety and Health, 3(1) pp. 94-106.

KBBI (2016) 'Kamus Besar Bahasa Indonesia ( KBBI )', Kementerian Pendidikan dan Budaya.

Ministry of Manpower (1970) 'Undang-undang Republik Indonesia Nomor 1 Tahun 1970 Tentang Keselamatan Kerja. Jakarta: Ministry of Manpower.

Kristianti, I. and Tualeka, A. R. (2019) 'Hubungan Safety Inspection dan Pengetahuan Dengan Unsafe Action di Departemen Rolling Mill', The Indonesian Journal of Occupational Safety and Health, 7(3), pp. 300-309.

Maslow, B. A. (1970) 'Maslow : Explanation of Hierarchy', Self.
Maulana, T. (2012) ‘Analisa Perilaku Kerja Karyawan Di De Boliva Surabaya Town Square', Jurnal Hospitality dan Manajemen Jasa, 1, pp. 563577.

Ningsih, A. R. and W. Ardyanto, Y. D. (2013) 'Evaluasi Pelaksanaan Behavior Based Safety Pada Program Stop Dalam Membentuk Perilaku Aman Tenaga Kerja Di Pt X Tahun 2013', The Indonesian Journal of Occupational Safety and Health, 2(1), pp. 35-44.

Pasaribu, G. S. (2020) 'Risk Assessment of Occupational Accident of the Riggers at PT $\mathrm{X}$ Surabaya', The Indonesian Journal of Occupational Safety and Health, 9(1), pp. 8187.

Pratiwi, H. Y. (2018) 'Analisis Penerapan Contractor Safety Management System (CSMS) di PT. X, Bontang, Kalimantan Timur', The Indonesian Journal of Occupational Safety and Health, 6(2), pp. 187-196.

Putri, I. P. singgih, Martiana, T. and Rahman, F. S. (2020) 'Correlation between Environmental and Individual Factors with Dermatitis Contact on Tobacco Farmers', The Indonesian Journal of Occupational Safety and Health, 9(1), pp. 95103.

Radityo, B. A. (2019) 'The Implementation of Sort, Set in Order, Shine, Standardize, and Sustain as Occupational Accident Preventions at PT X', The Indonesian Journal of Occupational Safety and Health, 8(3), pp. 292-301.

Septiani, N. (2018) 'Beberapa Faktor Yang Berhubungan Dengan Perilaku Pekerja Dalam Penerapan Safe Behavior Di PT. Hanil Jaya Steel', The Indonesian Journal of Occupational Safety and Health, 6(2), pp. 257-267.

Sirait, F. A. and Paskarini, I. (2017) 'Analisis Perilaku Aman pada Pekerja Konstruksi dengan Pendekatan Behavior-Based Safety (Studi di Workshop PT. X Jawa Barat)', The Indonesian Journal of Occupational Safety and Health, 5(1), pp. 91-100.

Syahfudin, A. J. (2019) 'Gambaran Faktor Internal dan Faktor Eksternal Kelelahan di Perusahaan Peleburan Baja Sidoarjo', The Indonesian Journal of Occupational Safety and Health, 8(3), pp. 336-345. 